\title{
Effect of Organic Particulate Matter on Vegetable Crops and their Control Potentials
}

\author{
Ida Munfarida ${ }^{1, *}$, Asep Sofyan ${ }^{2}$, and Arya Rezagama ${ }^{3}$ \\ ${ }^{1}$ Department of Environmental Engineering, Faculty of Science and Technology, Sunan Ampel State Islamic University \\ Surabaya, Surabaya - Indonesia \\ ${ }^{2}$ Department of Environmental Engineering, Faculty of Civil and Environmental Engineering, Bandung Institute of \\ Technology, Bandung - Indonesia \\ ${ }^{3}$ Department of Environmental Engineering, Faculty of Engineering, Diponegoro University, Semarang - Indonesia
}

\begin{abstract}
Air pollution has an impact, include impact to the plants. The adverse effects of air pollution have been associated with three major sources. They are gaseous pollutant and particulates from fossil fuels, manufacturing plants and vehicles. Many studies reveal that plants absorb particulate pollutants can cause damage or decline in growth. This study analysed the effects of organic particulate matter exposure on vegetable crops that were lettuce (Lactuta sativa $\mathrm{L}$ ) and cucumber (Cucumis sativus $\mathrm{L}$ ). Thus from the research we can control vegetable crops from particulate matter pollution. Growth parameters include the number of leaves, plant height, fresh weight, dry weight, number of chlorophyll and stomata index. This research was conducted on Padjadjaran University Greenhouse, Jatinangor. Lettuce and cucumber were given three treatment, those were: plant was contaminated with organic particulate matter derived from clay, plant inside and outside the chamber were not contaminated. The results showed that organic particulate matter exposure more affects the growth of lettuce than cucumbers for the following parameters: plant height, dry weight and fresh weight. Control potentials of organic particulate matter include regulation management, reducing field burning of vegetable residue, and implementation of particulate matter control devices in industry and vehicles.
\end{abstract}

Keywords: Air Pollution; Controlling; $\mathbf{P M}_{10}$; Vegetable Crops.

\section{Introduction}

The increasing in population growth has results in increasing food demand. Previous researchers have studied food demand by Huang \& Rozelle (1998), Abdulai, et.al (1999), Meenakshi \& Ray (1999), Fuller, et.al (2000), Gould (2002), Ma et.al (2004), Wang and Zhou (2005), Rae (2008), Dong \& Fuller (2010), Liu, et.al (2009), Gandhi and Zhou (2010), and Fu, et.al (2012) [112]. Regmi and Dyck (2001) have studied changes of food consumption across the countries [13]. And consumers are increasing their consumption on vegetables and fruits [14]. Global crop demand could increase from 5.5 to 10.9 Gton during 2011-2050 [15]. In the other hand, food productivity was threatened due to climate change. There is strong evidence that climate change affect food quality (diversity, nutrient density, and safety)[16-17]. This climate changes was caused by air pollution.

Air pollution has an impact, include impact to the plants. The adverse effects of air pollution have been associated with three major sources. They are gaseous pollutant and particulates from fossil fuels, manufacturing plants and vehicles. Many studies reveal that plants absorb particulate pollutants can cause damage or decline in growth [18-23].

In order to provide appropriate air pollution controlling in horticulture crops, we analysed the effects of organic particulate matter on vegetable crops that were lettuce (Lactuta sativa $\mathrm{L}$ ) and cucumber (Cucumis sativus L). The objective of the research was to analyze the effects of exposure of organic particulate matter on growth of lettuce (Lactuta sativa L) and cucumber (Cucumis sativus L) both morphology and physiology thus from the research we can control vegetable crops from air pollution.

Air pollution controlling on vegetable crops is one of the solution to mitigate vegetable quality and production. Good quality of vegetable crops will directly stimulate healthier society thus may results in developing low carbon society.

\footnotetext{
* Corresponding author: munfarida@uinsby.ac.id
} 


\section{MATERIALS AND METHODS}

\subsection{Area of Study}

This research was laboratory scale and was conducted on Padjadjaran University Greenhouse, Jatinangor, Sumedang District, West Java, Indonesia. It is located at 723 meters above sea level. The climate of the area is relatively temperate with an average rainfall of about $2500 \mathrm{~mm}$. The highest temperature recorded was $19^{\circ} \mathrm{C}$ $27^{0} \mathrm{C}$.

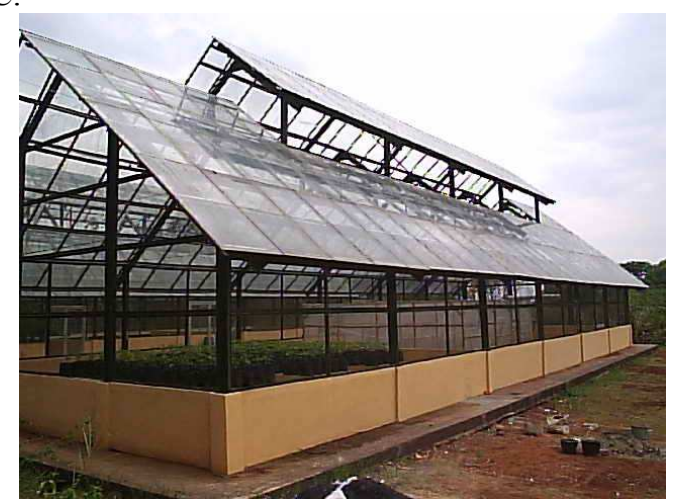

Fig. 1. Padjadjaran University Greenhouse

\subsection{Experimental Setup}

Lactuca sativa $\mathrm{L}$ and Cucumis sativus $\mathrm{L}$ were given three treatment, those were: plant was contaminated with organic particulate matter derived from clay, and plant inside and outside the chamber were not contaminated.

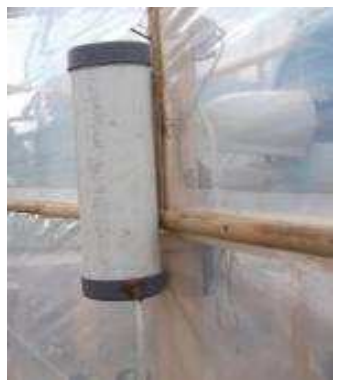

(a)

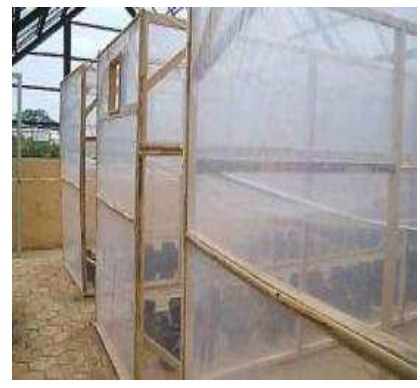

(b)
Fig. 1. Experimental Setup (a) clay (b) chamber design

\subsection{Air Pollution Monitoring}

Pollutant parameters measured in the chamber contaminated with organic particulate matter derived from clay was $\mathrm{PM}_{10}$. $\mathrm{PM}_{10}$ was monitored every 15 minute of 120 minute intervals for 4 (four) weeks.

\subsection{Plant Sampling and Analysis}

Plants were grown under field conditions in Green House. Plant samples were analysed every 7 days of intervals for 4 (four) weeks. Growth parameters include the number of leaves, plant height, fresh weight, dry weight, number of chlorophyll and stomata index.

ANOVA was used to determine the significant difference between treatments for the different variables and the Least Significant Difference (LSD) test at the 95\% probability level. All the statistical tests were performed using SPSS software (SPSS Inc., version 10).

\subsection{Stomata Observation}

Observation of leaf structure and stomata using light microscope with 400x enlargement and using Scanning Electron Microscope (SEM) was performed at Instrumentation Laboratory in ITB.

\section{RESULTS}

\subsection{Concentration of Particulate Pollutants}

The chamber was contaminated with clay, pollutant parameters measured was $\mathrm{PM}_{10}$. The results of particulate concentrations are shown in Table 1. During the exposure period, particulate concentration in clay chamber tends to be higher than the measured control levels both control inside or outside. Maximum particulate concentration was found at second week $\left(1.677,78 \mu \mathrm{g} / \mathrm{m}^{3}\right)$.

Table 1. Particuate Concentartion During Exposure Period

\begin{tabular}{|l|c|c|c|c|}
\hline \multirow{2}{*}{ Treatment } & \multicolumn{4}{|c|}{$\mathrm{PM}_{10}$ Concentration $\left(\mu \mathrm{g} / \mathrm{m}^{3}\right)$} \\
\cline { 2 - 5 } & $\begin{array}{c}\text { 1st } \\
\text { Week }\end{array}$ & $\begin{array}{c}\text { 2nd } \\
\text { Week }\end{array}$ & $\begin{array}{c}\text { 3rd } \\
\text { Week }\end{array}$ & $\begin{array}{c}\text { 4th } \\
\text { Week }\end{array}$ \\
\hline $\begin{array}{l}\text { Control } \\
\text { Outside }\end{array}$ & 200,97 & 198,46 & 22,69 & 55,56 \\
\hline $\begin{array}{l}\text { Control } \\
\text { Inside }\end{array}$ & 116,67 & 76,39 & 45,37 & 912,04 \\
\hline $\begin{array}{l}\text { Clay } \\
\text { Chamber } \\
\text { (Particulate) }\end{array}$ & 325,00 & $1.677,78$ & 195,27 & 95,83 \\
\hline
\end{tabular}

\subsection{Growth Response}

The results of growth response of $\mathrm{PM}_{10}$ exposure to the plant are shown in Table $2 \&$ Table 3 and Figure 3.. Plant growth parameters were plant height, number of leaves, plant fresh weight and plant dry weight.

Table 1. Plant Morphology Parameters on Lactuca Sativa L Exposed To Pollutant

\begin{tabular}{|l|l|l|l|}
\hline $\begin{array}{l}\text { Plant } \\
\text { Samples }\end{array}$ & $\begin{array}{l}\text { Control } \\
\text { Outside }\end{array}$ & $\begin{array}{l}\text { Control } \\
\text { Inside }\end{array}$ & $\begin{array}{l}\text { Particulate } \\
\text { Pollutant }\end{array}$ \\
\hline PH & $35.4167 \mathrm{a}$ & $44.6667 \mathrm{~b}$ & $40,0417 \mathrm{c}$ \\
\hline NL & $19.1250 \mathrm{a}$ & $21.9583 \mathrm{c}$ & $21,5417 \mathrm{bc}$ \\
\hline PFW & $135,9233 \mathrm{a}$ & $116,1994 \mathrm{~b}$ & $105,4480 \mathrm{~b}$ \\
\hline PDW & $12,3829 \mathrm{a}$ & $10,1888 \mathrm{~b}$ & $9,5594 \mathrm{~b}$ \\
\hline
\end{tabular}

Note: $\mathrm{y}=$ Means within columns having different letters are significantly different according to the least significant difference (LSD) at 0.05 level of probability. PH:Plant Height, NL: Number of Leaves, PFW: Plant Fresh Weight, PDW: Plant Dry Weight.

Treatment of particulate exposure was significant $(\mathrm{P}$ $<0.05$ ) on decrease of plant height of Lactuca sativa $\mathrm{L}$ compared to control inside rather than control outside (Sig $0.000<0.05)$. Meanwhile there was no significant 
difference on number of leaves from four treatments. Particulate exposure was significant $(\mathrm{P}<0.05)$ on decrease of plant fresh and dry weight of Lactuca sativa L compared to control outside rather than control inside $($ Sig $0.000<0.05)$.

Table 3. Plant Morphology Parameters on Cucumis Sativus Exposed To Pollutant

\begin{tabular}{|l|l|l|l|}
\hline $\begin{array}{l}\text { Plant } \\
\text { Samples }\end{array}$ & $\begin{array}{l}\text { Control } \\
\text { Outside }\end{array}$ & $\begin{array}{l}\text { Control } \\
\text { Inside }\end{array}$ & $\begin{array}{l}\text { Particulate } \\
\text { Pollutant }\end{array}$ \\
\hline PH & $118,9167 \mathrm{a}$ & $129,6625 \mathrm{~b}$ & $132,1875 \mathrm{~b}$ \\
\hline NL & $13.4583 \mathrm{a}$ & $25,9167 \mathrm{~b}$ & $27,4167 \mathrm{~b}$ \\
\hline PFW & $56,6351 \mathrm{a}$ & $69,3773 \mathrm{a}$ & $70,9403 \mathrm{a}$ \\
\hline PDW & $4,5298 \mathrm{a}$ & $6,1328 \mathrm{~b}$ & $6,9918 \mathrm{~b}$ \\
\hline
\end{tabular}

Note: $y=$ Means within columns having different letters are significantly different according to the least significant difference (LSD) at 0.05 level of probability. PH:Plant Height, NL: Number of Leaves, PFW: Plant Fresh Weight, PDW: Plant Dry Weight.

Based on statistical study, there was no effect of particulate exposure on reduction on growth of Cucumis sativus $\mathrm{L}(\mathrm{P}<0.05)$.

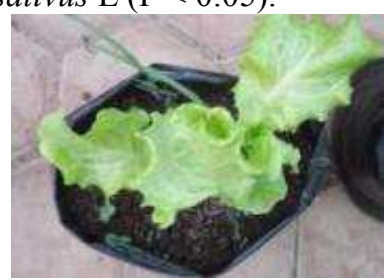

(a)

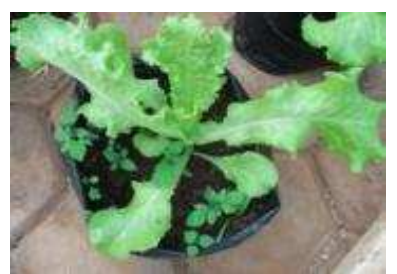

(b)

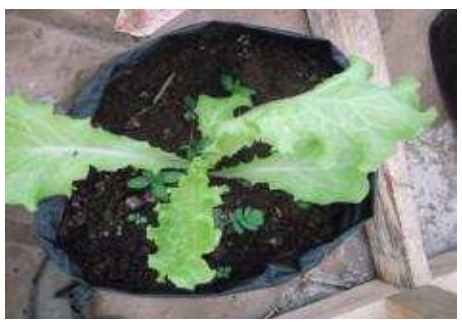

(c)

Fig. 3. Growth Responses of Lactuca sativa $\mathrm{L}$ to Particulate Exposure (a) control outside, (b) control inside,(c) Particulate exposure

\subsection{Physiological Response}

Physiological parameter was number of chlorophyll and stomata index. The results of physiological response of both plants to particulate exposure are shown in Figure 4 and Figure 5.

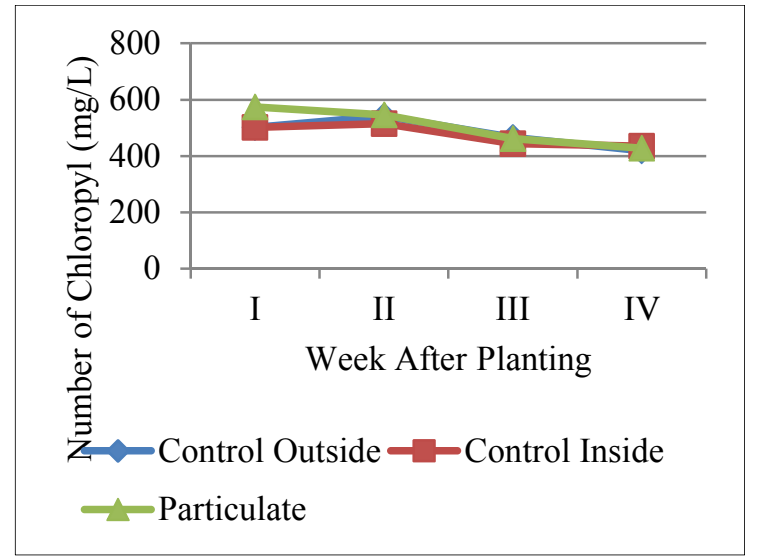

(a)

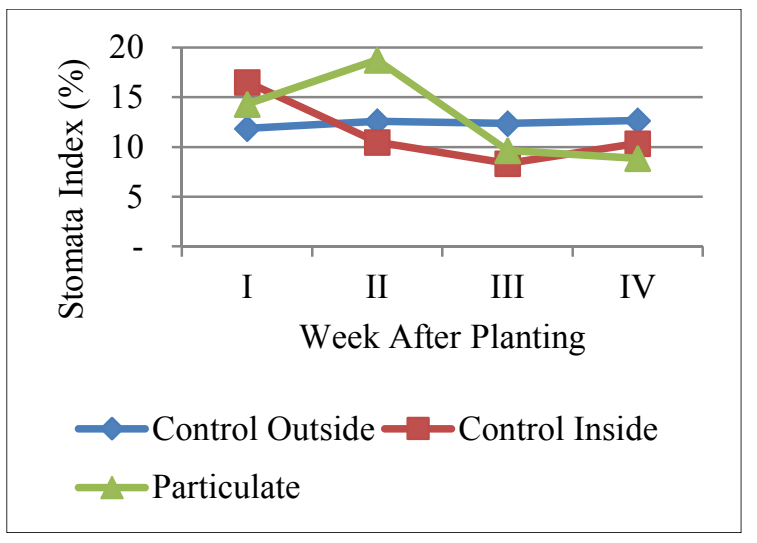

(b)

Fig. 4. Physiological Responses of Lactuca sativa L to Particulate Exposure

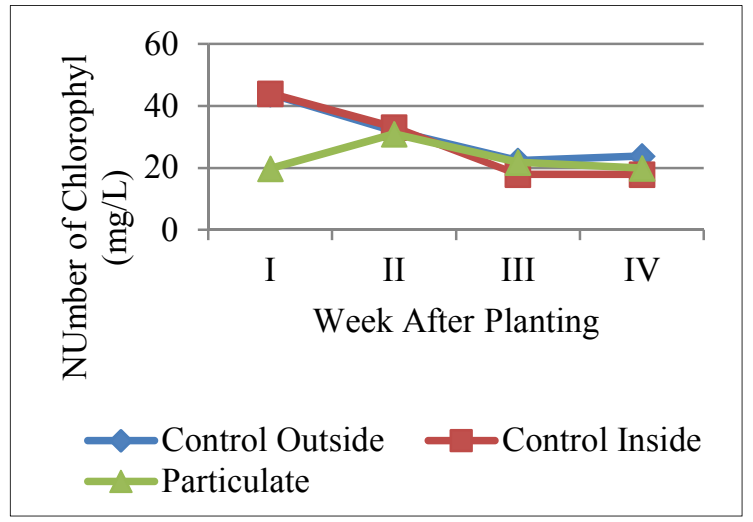

(a) 


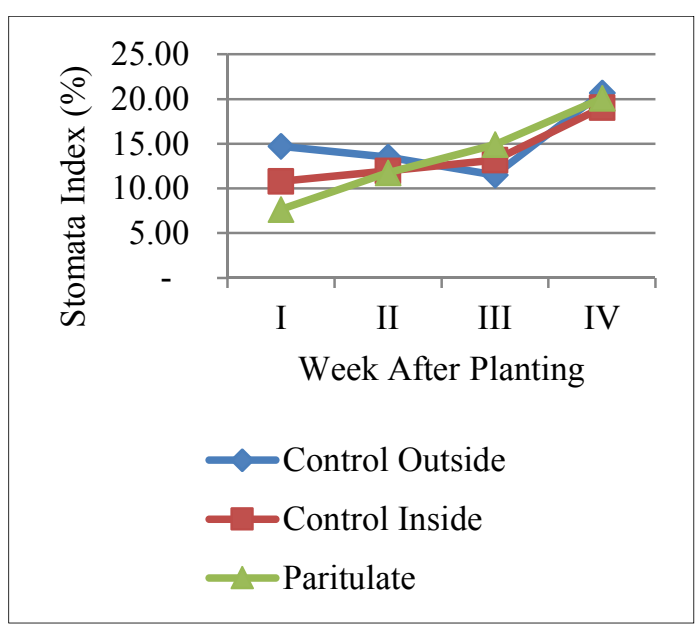

(b)

Fig. 5. Physiological Responses of Cucumis sativus $\mathrm{L}$ to Particulate Exposure

According to the study, there were no effect of particulate exposure on reduction on number of chlorophyll and stomata index of both plants during the particulate exposure period compared to control outside and control inside chamber.

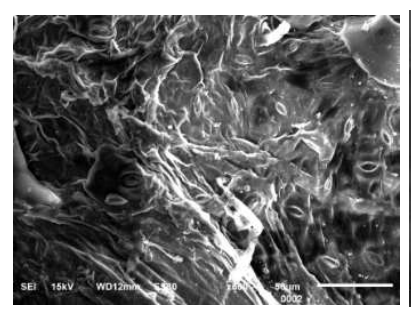

(a)

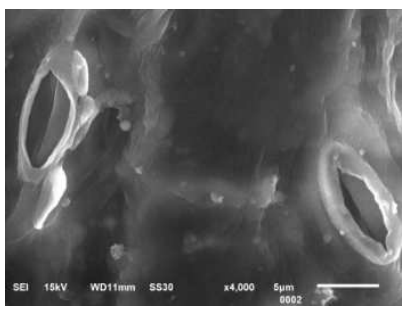

(b)

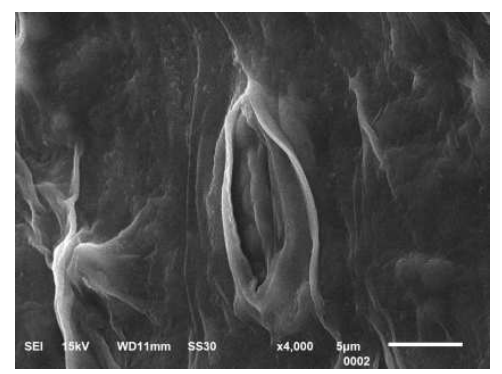

(c)

Fig. 6. Stomata of Lactuca satava L under SEM Observation (a) Control outside (b) Control inside (c) Particulate Exposure

\section{DISCUSSIONS}

Based on study, particulate exposure was significant $(\mathrm{P}<$ 0.05) on decrease of plant height, plant fresh and dry weight of Lactuca sativa L compared to control outside rather than control inside (Sig $0.000<0.05$ ).

Previous studies have been done on pollutant for damaging effect to the plant. The main responses are morphological and on the development of flowers and fruit [24]. Another study concludes that excess substance become toxic to the plant. This caused leaf chlorosis and root browning. Greater toxic substance concentration in the nutrient solution along with the appearance of toxicity symptoms significantly depressed the fresh mass of leaves, stems and roots [25]. Phosphate and nitrogen are plant nutrient in small quantities; excess nutrient will damage the plant. There is a complex change in physiological response due to excess substance. Plant cell may cause lysis and damage. Naama et.al on their study on fungal spores showed the allegenicity since the fungal spores were exposed to air pollution. This is due to protein nitration and deamidation [26].

Plants are the primary receptors for pollutants in the atmosphere including particulate matter. This is due to huge foliar surface area in the upper epidermis of the leaves that acts as natural sink for pollutant. The harmful effects of pollutant especially particulate matter on vegetation have already been note by many researchers [27-36]. From previous study, it showed that vegetation is an effective indicator of impact of air pollution especially particulate matter.

Based on study, the particulate exposure more affects the morphology of Lactuca sativa L than Cucumis sativus L. Impact of pollutant depends on the concentrations of elements in the chamber and the physiological status of the plant.

Previous study showed that phytotoxicity level of plant due to environmental contamination as follows: $Z$. mays $<C$. sativus $<L$. sativa $\mathrm{L}$. The results indicate inhibition in root elongation as the most sensitive toxicity end point for L. sativa L [37]. This study conclude that $C$. sativus $\mathrm{L}$ was tolerant vegetable to particulate pollutant than L. sativa L. The studies of the responses of species to air pollutants for their tolerance or sensitivity has been done by Gao et al. (2016); Mukherjee and Agrawal, (2016); Singh et al., 1991; and Wen et al.,(2004) [38-41].

Based on study, we may conclude that there was effect of the particulate pollutant to vegetable crops especially on the sensitive vegetables. Vegetable planting should consider air pollution controlling in order to maintain and enhance vegetable productivity. In Indonesia, air pollutants are the products of combustion from industrial area and transportation sectors which is currently developing. Olivier et.al (2016) reported that Indonesia (currently with a share of $1.4 \%$ of the global total $\mathrm{CO} 2$ emissions) showed a $4.0 \%$ increase in $\mathrm{CO} 2$ emissions in 2015, compared to 2014. These CO2 emissions derived from power and heat generation, other energy industry own use, manufacturing industry, road transport, other transport, residential sector, and other buildings [42]. Therefore, air pollutant controlling on vegetable crops include setting vegetable crops land away from industrial area and transportation sectors.

In Indonesia, the farmers used to burn crops residue after harvesting, therefore it may increase air pollutant exposure. Agricultural activities are the major human source of air pollution in rural areas. Majra (2011) stated that burning of stubble in the field after harvesting, 
threshing operation, grain dust and large scale use of tractors harvester, combines and diesels operated tube well are major factor contributing to air pollution [43]. According to Satyendra et.al (2013), burning of these residues emit gases like sulphur dioxide (SO2), oxides of nitrogen (NOx), carbon dioxide (CO2), carbon monoxide (CO), black carbon (BC), organic carbon (OC), methane (CH4), volatile organic compounds (VOC), non-methane hydrocarbons (NMHCs), ozone (O3), and aerosols which affect the global atmospheric [44]. Burning of crop residues emitted $8.57 \mathrm{Mt}$ of $\mathrm{CO}, 141.15 \mathrm{Mt}$ of CO2, 0.037 Mt of SOx, 0.23 Mt of NOx, 0.12 Mt of NH3 and 1.46 Mt NMVOC, $0.65 \mathrm{Mt}$ of NMHC, 1.21 Mt of particulate matter for the year 2008-09 in India [45]. These air pollutants may distribute in the atmosphere and may affect the crops planting on the other area. Based on fact, the air pollutant controlling on vegetable crops was avoiding open burning after harvesting. According to Satyendra et.al (2013), burning of crop residue/biomass can be avoided by adopting different biochemically/thermo-chemically induced techniques. Technologies are available for harnessing energy from crop residues are direct combustion, gasification, carbonisation, ethanol production, liquefaction, bricking and pyrolysis [44]. Other researchers suggest using agricultural residues as feedstock for biofuel production [46-47].

Author thanks to Ministry of Education, Republic of Indonesia, for Collaboration Research With Foreign Researcher and International Publication and Faculty of Environmental Engineering ITB.

\section{References}

1. J. Huang, S. Rozelle, China Eco. Re. 9, 25-45 (1998)

2. A. Abdulai, D. K. Jain, A. K. Sharma, J.of Agr. Eco. 50, 316-327 (1999)

3. J. V. Meenakshi, R. Ray, R, J.of Intl. Dev.11, 47-74 (1999)

4. F. Fuller, D. Hayes, D. Smith, Eco. Dev. \& Cultl. Change 49, 23-43 (2000)

5. B. W. Gould, Agr. 18, 387-407 (2002)

6. H. Ma, J. Huang, S. Rozelle, Eco. Dev.and Cultl. Change 52, 445-473 (2004)

7. J. M. Wang, Z. Y. Zhou, Aldershot:Ashgate 87-107 (2005)

8. A. Rae, Aus. Jour. of Agr. and Re. Eco. 52, 283-302 (2008)

9. F. Dong, F. Fuller, Can. Jour. of Agr. Eco. Rev. Can. d'agroeco. 58, 73-91 (2010)

10. H. Liu, K. A. Parton, Z. Y Zhou, R. Cox, Aus. Jour. of Agr. and Re. Eco. 53,1 (2009)

11. Gandhi, P. Vasant Z. Y Zhou, Aus. Agr. Rev. 18, 103-135 (2010)

12. Fu, Wenge, Gandhi, P. Vasant, Cao, Lijuan, Liu, Hongbo, Zhou, Zhangyue, Chi. \& Wrld Eco. 20, 88$106(2012)$

13. A. Regmi, J. Dyck, Effects of urbanization on global food demand. In A. Regmi (Ed.), Changing structures of global food consumption and trade. (ERS WRS 01-1, Economic Research Service, Washington, DC: United States Department of Agriculture 2001)

14. P. Vasant, Gandhi,Z. Zhangyue, Food Resour. Intl. 10, 963 (2014)

15. GLOPAN (Global Panel on Agriculture and Food Systems for Nutrition), Climate smart food systems for enhanced nutrition (London, 2015)

16. S. J. Vermeulen, B. M. Campbell, J. S. I. Ingram, Annu. Rev. Environ. Resour. 37, 195-222 (2012)

17. S. K. Prajapati, Environ.Skept.Critics 1,12-22 (2012)

18. U. Younis, T. Z. Bokhari, S. A. Malik, S. Ahmad, R. Raja, Int.J.Agric.Sci.Res.3,1-12 (2013)

19. P. K. Rai, L.S. Panda, B. Chutia, M. Singh, Afr.J.Environ.Sci. Technol.7, 944-948 (2013)

20. P. K. Rai, L. S. Panda, AirQual.Atmos.Health 7, 93101 (2014)

21. P. K. Rai, M .M. Singh, J.Asia-Pac.Biodivers. 8, 375 (2015)

22. P. K. Rai, Biomagnetic Monitoring through Roadside Plants of an Indo-Burma Hot Spot Region (Elsevier,UK, 2016)

23. P. K. Rai, J. Asia-Pac. Biodivers. 9, 47-55 (2016)

24. J. M. Wang, Z. Y. Zhou, Aldershot:Ashgate 87-107 (2005)

25. A. Rae, Aus. Jour. of Agr. and Re. Eco. 52, 283-302 (2008)

26. F. Dong, F. Fuller, Can. Jour. of Agr. Eco. Rev. Can. d'agroeco. 58, 73-91 (2010)

27. R. Misra, P. K. Behera, Pollut.Res. 13,203-206 (1994)

28. M. Farooq, K. R. Arya, S. Kumar, K. Gopal, P/ C. Joshi, R. K. Hans, J. Environ.Biol. 21,165-167 (2000)

29. N. Shrivastava, S. Joshi, Geobios 29,281-282 (2002)

30. I.N. Gostin, Not. Bot. Horti. Agrobot. Cluj-Napoca 37, 57-63 (2009)

31. D. Sukumaran, Effect of Particulate Pollution on various Tissue Systems of Tropical Plants (Central Pollution Control Board (CPCB), Zonal Office, Kolkata, India, 2012)

32. S. S. Garg, N. Kumar, G. Das, Indian J. Environ. Prot. 20,326-328 (2000)

33. J. Garty, O. Tamir, I. Hassid, A. Eshel, Y. Cohen,A. Karnieli,.J. Environ. Qual. 30,884-893 (2001)

34. P. M. Mashitha, V. I. Pise, Pollut. Res. 20,195-197 (2001)

35. J. G. Gavali, D. Saha,K. Krishnayya, Indian J. Environ. Health 44, 88-91 (2002)

36. P. K. Rai, Atmos. En-viron. 72,113-129 (2013)

37. K. Masakorala, J. Yao, H. Guo, R. Chandankere, J. Wang, M. Cai, H. Liu, M. M. F. Choi, W. A. S. Poll 224, 1553 (2013)

38. F. Gao, V. Calatayud, F. García-Breijo, J. ReigArmiñana, Z. Feng, Ecol. Indic. 67, 367 (2016)

39. A. Mukherjee, M. Agrawal, Bull. Environ. Contam. Toxicol. 96, 1-6 (2016)

40. S.K. Singh, D.N Rao, M. Agrawal, J. Pandey, D. Naryan, J. Environ. Manag. 32, 45-55 (1991)

41. D. Wen, Y. Kuang, G. Zhou, Environ. Sci. Pollut. Res. Int. 11, 165-170 (2004)

42. A. Mukherjee, M. Agrawal, Eco. E. S 152,42 (2018) 
43. J.G.J. Olivier, G. Janssens-Maenhout, M. Muntean, J. A.H.W. Peters, Trends in Global CO2 emissions: 2016 report (PBL Publishers, European Commission, 2016)

44. J.P. Majra, Air Quality in Rural Areas (INTECH, 2011)
45. T. Satyendra, R.N. Singh, S. Shaishav, Int. R. J. E. Sci 1, 24 (2013)

46. N. Jain, A. Bhatia, H. Pathak, Aer.A.Q.R 14, 422 (2014)

47. T. Searchinger, R. Heimlich, R. A. Houghton, F. Dong, A. Elobeid, J. Fabiosa, S. Tokgoz, D. Hayes, T. H. Yu, Sci, 319, 1238-1240 (2008) 